\title{
Attention as the basic component of cognitive functions of the brain and its features in children with bronchial asthma
}

\author{
S. M. Nedelska*A,F, O. Yu. Akulova ${ }^{\mathrm{B}, \mathrm{C}, \mathrm{D}}$, T. Ye. Shumna ${ }^{\mathrm{A}, \mathrm{E}}$ \\ Zaporizhzhia State Medical University, Ukraine
}

A - research concept and design; B - collection and/or assembly of data; C - data analysis and interpretation; D - writing the article;

$\mathrm{E}$ - critical revision of the article; $\mathrm{F}$ - final approval of the article

Purpose. To study the characteristics of attention in children with bronchial asthma (BA) taking into account their sex differences, depending on the course, duration and control of the disease.

Materials and methods. A psychological test (the Bourdon correction test) was performed in 101 children (71 boys and 30 girls) with BA and 30 practically healthy children (17 boys and 13 girls) aged 10-17 years who represented a control group.

The test results were evaluated by the indicator $S$ (sustained attention), calculated by the formula $0,5 \times \mathrm{N}-2,8 \times \mathrm{n} / \mathrm{t}$, where $\mathrm{N}$ the total number of characters viewed by the child in 150 seconds; $n$ - the number of errors; $t$ - reaction time ( 150 seconds). The results obtained were processed using the software package Statistica for Windows 13 (StatSoft Inc., № JPZ804I382130ARCN10-J).

Results. It has been determined that BA patients demonstrated a significantly higher number of errors than healthy children: $10.1 \pm 0.7$ versus $7.6 \pm 1.0$, indicating a decrease in the sustained attention. It has been established that the uncontrolled course of the disease negatively affected the level of $S$ that was lower than in healthy children $(1.17 \pm 0.05$ vs. $1.32 \pm 0.06)$ due to a decrease in attentional performance ( $404 \pm 17$ against $439 \pm 19$ ). Exacerbation and BA duration of more than 5 years led to a decrease in the level of $S$ compared with the control group ( $1.24 \pm 0.07$ vs. $1.32 \pm 0.06, P<0.05$ ).

Depending on sex, the $S$ score was lower in boys with BA than that in girls with BA and amounted to $1.23 \pm 0.03$ vs $1.39 \pm 0.04$ $(P<0.05)$ due to low attention span. However, in girls with a controlled course of $B A$, the $S$ indicator even exceeded the similar indicator of healthy girls $(1.52 \pm 0.07$ and $1.37 \pm 0.09)$.

Conclusions. Bronchial asthma children, especially boys with uncontrolled course, exacerbation and disease duration of more than 5 years, displayed attention problems as a reduction in attention span and sustained attention that should be considered as moderate manifestations of cognitive impairments. Therefore, self-management education in bronchial asthma children needs to take into account the reduced attentional indicators, and medical correction of an underlying disease should be accompanied by social and psychological support for patients.

\section{Увага як базова скиадова когнітивних функцій мозку та ії особливості в Аітей із бронхіальною астмою}

\section{С. М. Недельська, О. Ю. Акулова, Т. Є. Шумна}

Мета роботи - вивчити особливості уваги в дітей із бронхіальною астмою (БА), враховуючи відмінності за статтю, залежно від перебігу, тривалості та контрольованості хвороби.

Матеріали та методи. Використовуючи коректурну пробу Бурдона, здійснили психологічне тестування 101 дитини (71 хлопчик і 30 дівчат), які хворі на бронхіальну астму, та 30 практично здорових дітей (17 хлопчиків та 13 дівчаток) із контрольної групи віком 10-17 років.

Результати проби оцінювали за показником S (стійкість уваги), який обраховували за формулою $0,5 \times \mathrm{N}-2,8 \times \mathrm{n} / \mathrm{t}$, де N кількість знаків, які дитина переглянула; $\mathrm{n}$ - кількість помилок; $\mathrm{t}$ - час виконання завдання (150 секунд).

Результати опрацювали за допомогою пакета прикладних статистичних програм Statistica for Windows 13 (StatSoft Inc., № JPZ804I382130ARCN10-J).

Результати. Визначили, що кількість помилок у хворих на БА дітей вірогідно більша, ніж у здорових $(10,1 \pm 0,7$ проти $7,6 \pm 1,0)$, що свідчило про зниження концентрації уваги. Неконтрольований перебіг захворювання негативно впливав на показник рівня стійкості уваги (S), який був меншим, ніж у здорових $(1,17 \pm 0,05$ проти $1,32 \pm 0,06)$ внаслідок зниження продуктивності уваги (404 17 проти $439 \pm$ 19). Загострення і тривалість БА понад 5 років призводили до зниження показника стійкості уваги порівняно з групою контролю $(1,24 \pm 0,07$ проти $1,32 \pm 0,06, p<0,05)$.

У хлопчиків із БА показник S був нижчим, ніж у дівчат із БА і становив 1,23 $\pm 0,03$ проти 1,39 $\pm 0,04(p<0,05)$ внаслідок низької продуктивності уваги. У дівчат із контрольованим перебігом БА показник стійкості уваги навіть перевищував відповідний показник здорових дівчат $(1,52 \pm 0,07$ та 1,37 $\pm 0,09)$.

Висновки. У дітей, які хворі на БА (особливо хлопчиків) із неконтрольованим перебігом, загостренням і тривалістю хвороби понад 5 років, спостерігали розлади уваги, як-от зменшення обсягу та зниження стійкості уваги, котрі потрібно розглядати як помірні прояви когнітивних розладів. Навчання дітей прийомам самоконтролю БА необхідно здійснювати, враховуючи знижені показники уваги, а медична корекція основного захворювання має супроводжуватися соціально-психологічною підтримкою хворих.
Key words: attention, cognitive functions, cognitive impairment, bronchial asthma, children, Bourdon test.

\section{Zaporozhye} medical journal 2020; 22 (2), 215-219

${ }^{*} \mathrm{E}$-mail: nedelskaya.sn@zsmu. zp.ua

Кнючові слова: увага, когнітивні функції, когнітивні порушення, бронхіальна астма, Аіти, проба Бурдона.

Запорізький медичний журнал. 2020. T. 22, № 2(119). C. $215-219$ 
Ключевые слова: внимание, когнитивные функции, когнитивные нарушения, бронхиальная астма, Аети, проба Бурдона.

Запорожский медицинский журнал. 2020. T. 22, № 2(119). C. $215-219$

\section{Внимание как базовая составляющая когнитивных функций мозга и его особенности у детей с бронхиальной астмой}

\section{С. Н. Недельская, Е. Ю. Акулова, Т. Е. Шумная}

Цель работы - изучить особенности внимания у детей с бронхиальной астмой (БА), учитывая отличия по полу, в зависимости от течения, длительности и контролированности заболевания.

Материалы и методы. С использованием корректурной пробы Бурдона проведено психологическое тестирование 101 ребенка (71 мальчиков и 30 девочек) с бронхиальной астмой и 30 практически здоровых детей (17 мальчиков и 13 девочек) из контрольной группы в возрасте 10-17 лет.

Результаты пробы оценивали по показателю S (стойкость внимания), который высчитывали по формуле $0,5 \times \mathrm{N}-2,8 \times \mathrm{n} / \mathrm{t}$, где $\mathrm{N}$ - количество знаков, просмотренных ребенком; $\mathrm{n}$ - количество сделанных ошибок; $\mathrm{t}$ - время выполнения задания (150 секунд). Полученные данные обработаны при помощи пакета прикладных статистических программ Statistica for Windows 13 (StatSoft Inc., № JPZ804I382130ARCN10-J).

Результаты. Установлено, что количество сделанных ошибок у детей с БА достоверно выше, чем у здоровых $(10,1 \pm 0,7$ против $7,6 \pm 1,0)$, что свидетельствовало о снижении концентрации внимания. Неконтролированное течение заболевания негативно влияло на показатель уровня стойкости внимания (S), который был меньше, чем у здоровых $(1,17 \pm 0,05$ против $1,32 \pm 0,06)$ за счет снижения продуктивности внимания ( $404 \pm 17$ против $439 \pm 19)$. Обострение и длительность БА более 5 лет приводили к снижению показателя уровня стойкости внимания в сравнении с группой контроля $(1,24 \pm 0,07$ против $1,32 \pm 0,06, p<0,05)$. У мальчиков с БА показатель $S$ был более низким, чем у девочек с БА и составил 1,23 $\pm 0,03$ против $1,39 \pm 0,04(p<0,05)$ за счет низкой продуктивности внимания. У девочек при контролированном течении БА показатели

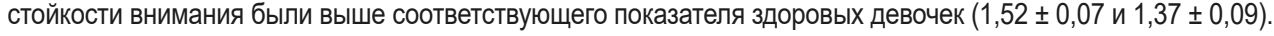

Выводы. У детей с БА (особенно мальчиков) с неконтролированным течением, обострением и длительностью болезни более 5 лет, отмечены нарушения внимания в виде уменьшения объема и снижения стойкости внимания, что необходимо рассматривать как умеренные проявления когнитивных расстройств. Обучение детей приемам самоконтроля БА необходимо осуществлять, учитывая сниженные показатели внимания, а медицинская коррекция основного заболевания должна сопровождаться социально-психологической поддержкой больных.

Attention is the concentration of consciousness and its focusing on something that is important for a person [1]. Attention is not considered as an isolated, independent mental process. It is a component (often a trigger) of all cognitive functions of a person - higher mental functions of the brain, which provide information perception, analysis, processing, remembering, storage and exchange of information, construction and implementation of an action program [2]. The launch of all these types of thought processes involves attentional control.

Attention is characterized by the following parameters:

1. Attention span (volume) - the number of symbols processed simultaneously;

2. Concentration - the ability to focus attention on one or more particular target stimuli but to suppress reactions to other irrelevant stimuli;

3. Sustaining, this is characterized by the duration of concentration, the ability not to be distracted during a certain period of time;

4. Switching - the ability to change the focus of attention, to move from one type of work to another;

5. Allocation - the ability for simultaneous execution of multiple actions.

Attention disorders are defined as mild cognitive impairments, which are presented in the ICD-10 as a separate nosological group under the code F90.0 "Attention-Deficit/ Hyperactivity Disorder". The incidence of attention deficit hyperactivity disorder in children is $7.6-10.0 \%$, that are markedly understated data according to some authors [3-7]. Often, such features are diagnosed at a quite late stage in children, when symptoms have already occurred, which are close to the psychiatric spectrum nosology. In such cases, the asocial moments of cognitive impairment dominate or pronounced child school maladjustment manifests itself. Somatically healthy children are diagnosed with mild cognitive impairments which are taken into account, albeit sometimes insufficiently, in contrast to children with chronic somatic diseases including those with bronchial asthma (BA), remaining a "blank page" in pediatrics. $[8,9]$. There is no data on the prevalence and characteristics of the course of these "mixed" states, prognosis for cognitive impairments or somatic pathology. Methodological approaches to early diagnosis have not been developed due to the lack of interdisciplinary interaction between pediatricians, psychologists, neurologists, defectologists in the process of monitoring a child. In pediatrics, cognitive disorders have not yet been fully recognized and accorded the proper significance and, unfortunately, not viewed through the lens of clinical relevance for therapy and rehabilitation of a child with underlying diseases, particularly with BA.

It is also necessary to emphasize the special social significance of mild cognitive impairment, including attention deficit disorder with hyperactivity disorder for a child and his family [10]. Attention and memory are interrelated functions of a person's thinking, therefore a child with an attention deficit disorder has a hard time doing school subjects, may be a non-achiever, which leads to school maladjustment, poor relationships with peers, and negative attitude towards school, teachers, which in turn are compounded by family conflicts. This is the negative background that forms the changed personality with a high readiness for deviant behavior and other negative social consequences. That is the "unimportance" at first sight of such a medical and social defect as an attentional impairment and its non-diagnosability can have severe emotional, personal and social consequences for a child already struggling with such a serious illness as BA. All the above facts explain the need to address the problem of mild cognitive impairment, in particular, attention in BA children. 


\section{Aim}

To study the characteristics of attention in children with BA taking into account their sex differences, depending on the course, duration and control of the disease.

\section{Materials and methods}

The medical-psychological tests were performed in the main study group of children (children with BA) and the control group (healthy children) using Bourdon test. The main study group was composed of 101 children ( 71 boys and 30 girls) aged 10-17 years with a diagnosis of BA, who received inpatient treatment at the Allergic Department of the City Multi-Profile Children's Hospital No. 5 in Zaporizhzhia.

The control group consisted of 30 practically healthy age- and sex-matched children (17 boys and 13 girls), with the absence of neurological, bronchial, pulmonary and cardiovascular diseases. The criteria for inclusion in the main study group were: age of 10-17 years, diagnosis of BA, absence of central nervous system (hypoxic, toxic, traumatic or inflammatory genesis) and focal brain pathology history, absence of complaints and manifestations of neurologic pathology according to neurological examination at the beginning of the study. Children with $B A$ received traditional basic therapy based on the "Unified clinical protocol of primary, secondary (specialized) medical care", approved by the order of the Ministry of Health of Ukraine No. 868 dated 08.10.2013. The parents of all participants were given an explanation about the methods and scope of examination and voluntarily signed a written informed consent to participate in the study following the Declaration of Helsinki Principles, "Model Regulations of the Ethics Committees at health care settings which conduct clinical trials", approved by order of the Ministry of Health of Ukraine No. 690 dated September 23, 2009. For the purpose of the study, children of the main group were tested twice - initially and repeatedly 3 months after the treatment. Bourdon correction test was performed using special forms with randomly placed letters in accordance with the generally accepted method [11]. This test made it possible to determine the following of the five characteristics of attention: attention span, concentration and sustaining. Sample results were evaluated based on the number of characters viewed and the number of crossed characters. The results of processing included:

1. Counting the number of characters viewed by the child in 150 seconds, which characterizes the attention span (volume).

2. Counting the number of errors made by the child in 150 seconds, which characterizes the sustained attention.

3. Calculation of $S$ indicator (sustained attention), which characterizes the sustainability of attention and is a general indicator of the development level of two attentional characteristics in the child - the productivity and concentration. It reflects the impact of long-term work on sustained attention. This indicator was calculated by the formula:

$$
0,5 \times N-2,8 \times n / t
$$

where: $\mathrm{S}$ - sustained attention; $\mathrm{N}$ - the number of characters viewed by the child in 150 seconds; $n$ - the number of errors made by the child in 150 seconds; $\mathrm{t}$ - reaction time ( 150 seconds).
Table 1. Indicators of attention in patients with bronchial asthma compared with healthy children according to the Bourdon test $(\mathrm{M} \pm \mathrm{m})$

\begin{tabular}{l|l|l} 
Indicator & $\begin{array}{l}\text { Children with bronchial } \\
\text { asthma }(\mathbf{n}=101)\end{array}$ & $\begin{array}{l}\text { Healthy children } \\
(\mathbf{n}=30)\end{array}$ \\
\hline Number of characters in $150 \mathrm{sec}$ & $438 \pm 9$ & $439 \pm 19$ \\
Number of errors & $10.1 \pm 0.7^{*}$ & $7.6 \pm 1.0$ \\
\hline Indicator of S & $1.27 \pm 0.03$ & $1.32 \pm 0.06$ \\
\hline
\end{tabular}

*: the differences are significant between $B A$ and healthy children $(P<0.05)$.

Given the absence of these three indicators normative values, their analysis was performed by comparison with similar indicators of healthy children, as well as depending on the degree of control, the duration of BA and the treatment results. The results obtained were processed by the method of variation statistics using the software package Statistica for Windows 13 (StatSoft Inc., № JPZ804I382130ARCN10-J).

\section{Results}

According to the Bourdon test results, the general indicators of the attention in BA patients in comparison with healthy children were determined and presented in Table 1.

The number of errors made by BA patients was statistically significantly higher than in healthy subjects: $10.1 \pm 0.7$ versus $7.6 \pm 1.0(P<0.05)$, which indicated a decrease in the sustained attention in BA children. Attentional indicators of BA children depending on the degree of BA control according to the Bourdon test results are presented in Table 2.

The uncontrolled course of the disease negatively affected the attentional indicators, namely: the level of $S$, which was lower than in healthy children $-1.17 \pm 0.05$ versus $1.32 \pm 0.06(P=0.05)$ due to a decrease in attentional performance $-404 \pm 17$ versus $439 \pm 19(P=0.01)$, respectively. Exacerbation and $\mathrm{BA}$ duration of more than 5 years led to a decrease in the level of $S$ compared with the control group ( $1.24 \pm 0.07$ vs. $1.32 \pm 0.06, P<0.05$ ).

A number of sources of scientific and research literature refer to the presence of certain sex characteristics of the BA course in children [5,7], therefore, in our study, we carried out a gender analysis of attention indicators (Table 3).

Thus, in boys with BA, the S-attention indicator was significantly lower than in girls with $B A-1.23 \pm 0.03$ versus $1.39 \pm 0.04$, respectively $(P=0.01)$ due to low attention performance $424 \pm 11$ versus $474 \pm 15(P=0.01)$, respectively. In girls with $B A$, the indicators of attention did not differ from the similar indicators in healthy girls. The sex-specific features were not found in the control group (healthy children).

We have also performed a gender analysis of attention indicators depending on the degree of BA control (Table 4).

According to Table 4, the lowest indicator of $S$ was recorded in boys with uncontrolled course of $B A$, which was significantly different from that in healthy boys $-1.13 \pm 0.06$ and $1.28 \pm 0.07$, respectively $(P=0.05)$. The indicators of $S$ in uncontrolled and partially controlled course of the disease were significantly lower in boys than that in girls. The girls with BA showed a specific dynamics: in the uncontrolled course of $B A$, the indicators of $S$ was significantly lower than in healthy girls $-1.23 \pm 0.07$ and $1.37 \pm 0.09(P=0.05)$, respectively, the indicator of $S$ was increased after BA control achieving and even exceeded the similar indicator in healthy girls $-1.52 \pm 0.07$ and $1.37 \pm 0.09(P=0.05)$, respectively. 
Table 2. Attentional indicators of children with bronchial asthma depending on the degree of bronchial asthma control according to the Bourdon test results $(\mathrm{M} \pm \mathrm{m})$

\begin{tabular}{|c|c|c|c|c|}
\hline \multirow[t]{2}{*}{ Test indicator } & \multirow{2}{*}{$\begin{array}{l}\text { Healthy children } \\
(n=30)\end{array}$} & \multicolumn{3}{|c|}{ Children with bronchial asthma $(n=143)$} \\
\hline & & $\begin{array}{l}\text { Uncontrolled course } \\
\text { of bronchial asthma }(n=36)\end{array}$ & $\begin{array}{l}\text { Partially controlled course } \\
\text { of bronchial asthma ( } n=47 \text { ) }\end{array}$ & $\begin{array}{l}\text { Controlled course } \\
\text { of bronchial asthma }(n=60)\end{array}$ \\
\hline Number of characters in $150 \mathrm{sec}$ & $439 \pm 19$ & $404 \pm 17^{* *}$ & $431 \pm 15$ & $465 \pm 15^{11}$ \\
\hline Number of errors & $7.6 \pm 1.0$ & $9.9 \pm 1.4$ & $10.6 \pm 1.5$ & $9.9 \pm 0.8$ \\
\hline Indicator of S & $1.32 \pm 0.06$ & $1.17 \pm 0.05^{*}$ & $1.24 \pm 0.05$ & $1.27 \pm 0.03^{1}$ \\
\hline
\end{tabular}

The differences are significant:

$*$ : in the indicator $S$ between patients with uncontrolled course of $B A$ and healthy children, $P=0.05 ; * *$ : in the number of characters in 150 seconds between patients with uncontrolled course of $B A$ and healthy children, $P=0.01 ;{ }^{1}$ : in sustained attention between patients with controlled and uncontrolled course of $B A, P=0.01 ;{ }^{11}$ : in the number of characters between patients with controlled and uncontrolled course of $B A, P=0.05$.

Table 3. Attention indicators in boys and girls with bronchial asthma in comparison with healthy children according to the Bourdon test results ( $\mathrm{M} \pm \mathrm{m}$ )

\begin{tabular}{l|l|l|l|l}
\multirow{2}{*}{ Test indicator } & \multicolumn{2}{|l|}{ Healthy children } & \multicolumn{2}{l}{ Children with bronchial asthma } \\
\cline { 2 - 5 } & Boys $(\mathbf{n}=\mathbf{1 7})$ & Girls $(\mathbf{n}=13)$ & Boys $(\mathbf{n}=\mathbf{7 1})$ & Girls $(\mathbf{n}=\mathbf{3 0})$ \\
\hline Number of characters in $150 \mathrm{sec}$ & $423 \pm 25$ & $456 \pm 29$ & $424 \pm 11$ & $474 \pm 15^{*}$ \\
Number of errors & $7.3 \pm 1.3$ & $8.0 \pm 1.7$ & $10.0 \pm 0.8$ & $10.6 \pm 1.2$ \\
\hline Indicator of S & $1.28 \pm 0.07$ & $1.37 \pm 0.09$ & $1.23 \pm 0.03$ & $1.39 \pm 0.04^{* *}$ \\
\hline
\end{tabular}

The differences are significant:

*: in the number of characters in 150 seconds between boys and girls with $B A, P=0.01 ; * *$ : in the indicator $S$ between boys and girls with $B A, P=0.01$.

Table 4. Attention indicators in boys and girls depending on the degree of bronchial asthma control according to Bourdon test results ( $M \pm m$ )

\begin{tabular}{|c|c|c|c|c|c|c|c|c|}
\hline \multirow[t]{3}{*}{ Test indicator } & \multirow{2}{*}{\multicolumn{2}{|c|}{ Healthy children }} & \multicolumn{6}{|c|}{ Children with bronchial asthma } \\
\hline & & & \multicolumn{2}{|c|}{$\begin{array}{l}\text { Uncontrolled course } \\
\text { of bronchial asthma }\end{array}$} & \multicolumn{2}{|c|}{$\begin{array}{l}\text { Partially controlled course } \\
\text { of bronchial asthma }\end{array}$} & \multicolumn{2}{|c|}{$\begin{array}{l}\text { Controlled course } \\
\text { of bronchial asthma }\end{array}$} \\
\hline & $\begin{array}{l}\text { Boys } \\
n=17\end{array}$ & $\begin{array}{l}\text { Girls } \\
n=13\end{array}$ & $\begin{array}{l}\text { Boys } \\
n=24\end{array}$ & $\begin{array}{l}\text { Girls } \\
n=12\end{array}$ & $\begin{array}{l}\text { Boys } \\
n=33\end{array}$ & $\begin{array}{l}\text { Girls } \\
n=14\end{array}$ & $\begin{array}{l}\text { Boys } \\
n=44\end{array}$ & $\begin{array}{l}\text { Girls } \\
n=16\end{array}$ \\
\hline Number of characters in $150 \mathrm{sec}$ & $423 \pm 25$ & $456 \pm 29$ & $398 \pm 23$ & $415 \pm 24$ & $413 \pm 18$ & $476 \pm 25$ & $446 \pm 17$ & $525 \pm 24$ \\
\hline Number of errors & $7.3 \pm 1.3$ & $8.0 \pm 1.7$ & $10.6 \pm 2.0$ & $8.8 \pm 1.7$ & $10.3 \pm 1.8$ & $11.3 \pm 2.7$ & $9.3 \pm 0.9$ & $12.1 \pm 1.9$ \\
\hline Indicator of S & $1.28 \pm 0.07$ & $1.37 \pm 0.09$ & $1.13 \pm 0.06^{*}$ & $1.23 \pm 0.07^{1}$ & $1.18 \pm 0.05$ & $1.38 \pm 0.08^{\star \star \star}$ & $1.31 \pm 0.07^{11}$ & $1.52 \pm 0.07^{*}$ \\
\hline
\end{tabular}

The differences are significant: *: between healthy boys and boys with uncontrolled course of $B A, P=0.05$; **: between healthy girls and girls with controlled course of $B A, P=0.04$; $* * *$ : between boys and girls with partially controlled course of $B A, P=0.04 ;{ }^{1:}$ between girls with uncontrolled course of $B A$ and girls with controlled course of $B A, P=0.01 ;{ }^{11}$ : between boys and girls with controlled course of $\mathrm{BA}, \mathrm{P}=0.04$.

\section{Discussion}

In modern medicine, the development of cognitive pediatrics is relevant, when the cognitive status (cognitive intelligence) and cognitive performance in a child, social support if necessary, are included in the assessment of disease severity prognosis [12]. Children suffering from BA also need such cognitive support, since the studies conducted have shown the presence of negative changes, namely the reduction in the attentional performance in BA children: a decrease in both the attention span and the level of sustained attention, which may indicate inertia in attentional parameters.

The attention span is limited. Remembering of a large amount of data requires quite a long-term concentration. Exacerbation and BA duration of more than 5 years negatively affected the indicators of attention in all the children with BA. The risk contingent, in our opinion, includes boys with $B A$ who have lower levels of the disease control than healthy boys and girls with varying levels of BA control. Since there were no clinical manifestations of neurological pathology in BA children in our study, attention disorders should be considered as moderate (mild) or preclinical manifestations of cognitive impairment. These cognitive peculiarities of sick children should be taken into account by all the participants of the treatment process: doctors, the child and his/her parents, but first of all, a pediatrician during the sanitary and educational work in the institutions of primary health care, specialized institutions, while giving "Asthma education" classes, during individual conversations with a sick child and his/her parents. The teaching a child in methods and ways of asthma self-management needs to take into account the reduced attentional indicators in this contingent of patients.

The cognitive development of a child is a multidisciplinary problem which falls within the scope of pedagogy, pediatrics, neurology, psychology, neurophysiology, pharmacology, and other areas of science and practice $[13,14]$. Future child-rearing practices will include a safety assessment and further development of the brain cognitive functions [15]. It is not surprising therefore that the great teacher V. O. Sukhomlynskyi compared the child's brain metaphorically and poetically to a rose flower and called for its care. In the process of achieving BA control, medical correction should be complemented by a social and psychological one, when a pediatrician and a medical (school) psychologist analyze the cognitive portrait of a child and make sure to inform parents.

Features of the brain cognitive state in BA children, pathogenetic mechanisms of BA development and course as well as its influence on cognitive functions require in-depth systematic scientific research. Our report 1 has identified the presence of cognitive impairment in children with BA. This issue needs to be further studied, and our next reports will highlight possible reasons for such changes. 


\section{Conclusions}

1. In children with bronchial asthma, inability to focus attention is observed in the form of decreased both the attention span and the level of sustained attention.

2. Bronchial asthma children, especially boys with uncontrolled course, exacerbation and disease duration of more than 5 years, displayed attention problems as a reduction in attention span and sustained attention that should be considered as moderate manifestations of cognitive impairments.

3. Self-management education in bronchial asthma children needs to take into account the reduced attentional indicators.

4. Medical correction of an underlying disease should be accompanied by a social and psychological support for patients.

Prospects for further researches. In the future, we expect to identify the causes of cognitive impairment in BA children.

\section{Funding}

The study presented is a fragment of the scientific and research work of Zaporizhzhia State Medical University: "Optimization of differential diagnostics and treatment of allergic and other diseases in children of different ages" (state registration number 0118U004254), 2018-2022.

Conflicts of interest: authors have no conflict of interest to declare. Конфмікт інтересів: віАсутній.

Надійшла до редакції / Received: 04.07.2019

Після Аоопрацювання / Revised: 10.08.2019

Прийнято Ао Аруку / Accepted: 13.08.2019

Information about authors:

Nedelska S. M., MD, PhD, DSc, Professor of the Department of Faculty Pediatricy, Zaporizhzhia State Medical University, Ukraine.

Akulova 0. Yu., MD, Assistant of the Department of Faculty Pediatricy, Zaporizhzhia State Medical University, Ukraine. Shumna T. Ye., MD, PhD, DSc, Professor of the Department of Faculty Pediatricy, Zaporizhzhia State Medical University, Ukraine.

\section{Відомості про авторів:}

НеАельська С. М., А-р меА. наук, професор,

зав. каф. факультетської педіатрії, Запорізький Аержавний медичний університет, Україна.

Акулова О. Ю., асистент каф. факультетської педіатрії, Запорізький Аержавний медичний університет,

Україна.

Шумна Т. Є., А-р меА. наук, професор каф. факультетсько педіатрії, Запорізький Аержавний медичний університет, Україна.

\section{Сведения об авторах:}

Недельская С. Н., А-р меА. наук, профессор, зав. каф. факультетской педиатрии, Запорожский государственный медицинский университет, Украина.

Акулова Е. Ю., ассистент каф. факультетской педиатрии, Запорожский госуАарственный меАицинский университет, Украина;

Шумная Т. Е., А-р меА. наук, профессор каф. факультетской педиатрии, Запорожский госуАарственный меАицинский университет, Украина.
References

[1] Boulet, L. -P., Reddel, H. K., Bateman, E., Pedersen, S., FitzGerald, J. M., \& O'Byrne, P. M. (2019). The Global Initiative for Asthma (GINA): 25 years later. European Respiratory Journal, 54(2), Article 1900598. https://doi.org/10.1183/13993003.00598-2019

[2] Solovyova, A. P., Goryachev, D. V., \& Arkhipov, V. V. (2018). Kriteril otsenki kognitivnykh narushenii v klinicheskikh issledovaniyakh [Criteria for Assessment of Cognitive Impairment in Clinical Trials]. The Bulletin of the Scientific Centre for Expert Evaluation of Medicinal Products, 8(4), 218-230. https://doi.org/10.30895/1991-2919-2018-8-4-218-230

[3] Párraga, J. L., Calleja Pérez, B., López-Martín, S., Albert, .J, Martín Fernández-Mayoralas, D., Fernández-Perrone, A. L., Jiménez de Domingo, A., Tirado, P., López-Arribas, S., Suárez-Guinea, R., \& Fernández-Jaén, A. (2019). Attention-deficit/hyperactivity disorder and lifestyle habits in children and adolescents. Actas espanolas de psiquiatria, 47(4),158-164.

[4] Banjari, M., Kano, Y., Almadani, S., Basakran, A., Al-Hindi, M., \& Alahmadi, T. (2018). The Relation between Asthma Control and Quality of Life in Children. International Journal of Pediatrics, 2018, Article 6517329. https://doi.org/10.1155/2018/6517329

[5] Schans, J. V., Çiçek, R., de Vries, T. W., Hak, E., \& Hoekstra, P. J. (2017). Association of atopic diseases and attention-deficit/hyperactivity disorder: A systematic review and meta-analyses. Neuroscience \& Biobehavioral Reviews, 74(Pt. A), 139-148. https://doi.org/10.1016/j. neubiorev.2017.01.011

[6] World Health Organization. (2019). International statistical classification of diseases and related health problems (11th ed.). https://icd.who.int/

[7] Yang, C. - F., Yang, C. -C., \& Wang, I. -J. (2018). Association between allergic diseases, allergic sensitization and attention-deficit/hyperactivity disorder in children: A large-scale, population-based study. Journal of the Chinese Medical Association, 81(3), 277-283. https:// doi.org/10.1016/j.jcma.2017.07.016

[8] Akulova, O. Y. (2012). Metodolohichni pytannia doslidzhennia osobystosti khvoroi na khronichnu patolohiiu dytyny shkilnoho viku (na prykladi bronkhialnoi astmy) [Methodological questions of research of personality of school's age child by chronic pathology (on example of bronchial asthma)]. Aktualni pytannia medychnoi nauky ta praktyky, 1(79), 3-7. [in Ukrainian].

[9] Dudeney, J., Sharpe, L., Sicouri, G., Lorimer, S., Dear, B. F., Jaffe, A. Selvadurai, H., \& Hunt, C. (2017). Attentional Bias in Children with Asthma with and without Anxiety Disorders. Journal of Abnormal Child Psychology, 45(8), 1635-1646. https://doi.org/10.1007/s10802-017-0261-1

[10] Baiardini, I., Sicuro, F., Balbi, F., Canonica, G. W., \& Braido, F. (2015). Psychological aspects in asthma: do psychological factors affect asthma management? Asthma Research and Practice, 1(7). https:// doi.org/10.1186/s40733-015-0007-1

[11] (1995). Al'manakh psikhologicheskikh testov [Almanac of psychological tests]. KSP. [in Russian].

[12] Lizasoain, O. (2015). Siblings of a Child with a Serious Disease: Educational Family Guidelines for Developing the Emotional Health of This Minority Group. Open Journal of Social Sciences, 3(8), 56-60. https://doi.org/10.4236/jss.2015.38005

[13] Walter, H., Sadeque-lqbal, F., Ulysse, R., Castillo, D., Fitzpatrick, A., \& Singleton, J. (2015). The effectiveness of school-based family asthma educational programs on the quality of life and number of asthma exacerbations of children aged five to 18 years diagnosed with asthma: a systematic review protocol. JBI Database of Systematic Reviews and Implementation Reports, 13(10), 69-81. https://doi.org/10.11124/ jbisrir-2015-2335

[14] Class, Q. A., Van Hulle, C. A., Rathouz, P. J., Applegate, B., Zald, D. H., \& Lahey, B. B. (2019). Socioemotional dispositions of children and adolescents predict general and specific second-order factors of psychopathology in early adulthood: A 12-year prospective study. Journal of Abnormal Psychology, 128(6), 574-584. https://doi.org/10.1037/ abn0000433

[15] Ruiz-Goikoetxea, M., Cortese, S., Aznarez-Sanado, M., Magallón, S., Alvarez Zallo, N., Luis, E. O., de Castro-Manglano, P., Soutullo, C., \& Arrondo, G. (2018). Risk of unintentional injuries in children and adolescents with ADHD and the impact of ADHD medications: A systematic review and meta-analysis. Neuroscience \& Biobehavioral Reviews, 84, 63-71. https://doi.org/10.1016/j.neubiorev.2017.11.007 